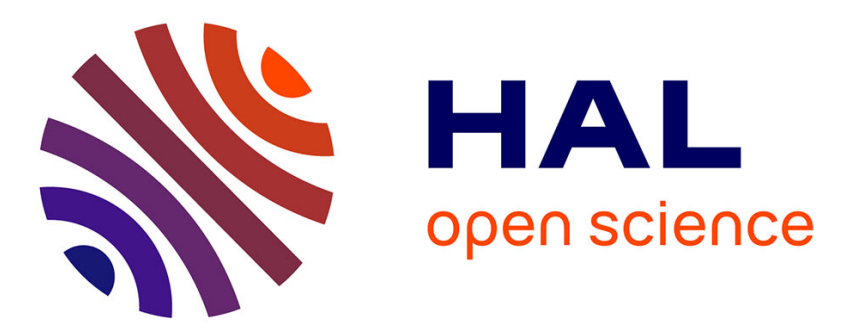

\title{
Characterisation of European varieties of triticale with special emphasis on the ability of plant phytase to improve phytate $\mathbf{P}$ availability to chickens
}

Yves Nys

\section{- To cite this version: \\ Yves Nys. Characterisation of European varieties of triticale with special emphasis on the ability of plant phytase to improve phytate P availability to chickens. British Poultry Science, 2007, 48 (06), pp.678-689. 10.1080/00071660701691292 . hal-00545322}

\section{HAL Id: hal-00545322 \\ https://hal.science/hal-00545322}

Submitted on 10 Dec 2010

HAL is a multi-disciplinary open access archive for the deposit and dissemination of scientific research documents, whether they are published or not. The documents may come from teaching and research institutions in France or abroad, or from public or private research centers.
L'archive ouverte pluridisciplinaire HAL, est destinée au dépôt et à la diffusion de documents scientifiques de niveau recherche, publiés ou non, émanant des établissements d'enseignement et de recherche français ou étrangers, des laboratoires publics ou privés. 


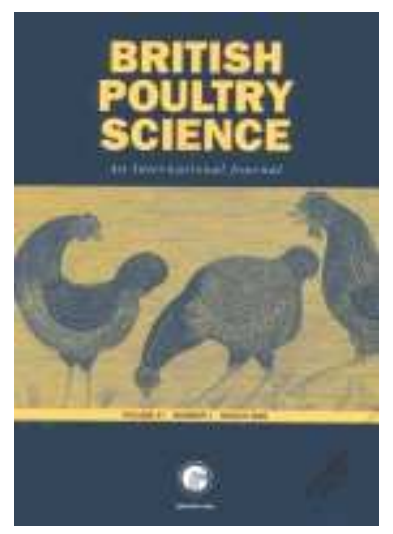

Characterisation of European varieties of triticale with special emphasis on the ability of plant phytase to improve phytate $P$ availability to chickens

\begin{tabular}{|r|l|}
\hline Journal: & British Poultry Science \\
\hline Manuscript ID: & CBPS-2007-148 \\
\hline Manuscript Type: & Original Manuscript \\
\hline Date Submitted by the \\
Author: & $15-J u n-2007$ \\
\hline Complete List of Authors: & Nys, Yves; INRA, Recherches Avicoles \\
\hline Keywords: & chicken, triticale, phytase, phosphorus, viscosity \\
\hline
\end{tabular}

\section{s ScholarONE" \\ Manuscript Central}


Characterisation of European varieties of triticale with special emphasis on the ability of

plant phytase to improve phytate phosphorus availability to chickens

9 Institut National de la Recherche Agronomique INRA, UMR1079 Systèmes d'élevage

10 Nutrition Animale et Humaine, Agrocampus, F-35590 Saint-Gilles, ${ }^{1}$ INRA, UR83 Recherches

11 Avicoles, F-37380 Nouzilly, ${ }^{2}$ INRA UMR1095 Amélioration et Santé des Plantes, Domaine de

12 Crouelle, UBP, F-63000 Clermont-Ferrand, France

To whom correspondence should be addressed.

Fax: +33 (0) 247427778 
1 Abstract 1. A total of 30 varieties and selection lines of triticale grown under similar

2 conditions were characterised. Thousand grain weight, specific weight, Hagberg falling

3 number and $\mathrm{N}$ were $50.2 \pm 5.0 \mathrm{~g}, 72.4 \pm 2.1 \mathrm{~kg} / \mathrm{hl}, 96 \pm 48 \mathrm{~s}$ and $16.1 \pm 0.11 \mathrm{~g} / \mathrm{kg}$,

4 respectively.

5 2. Mean phosphorus (P) concentration was $2.86 \pm 0.31 \mathrm{~g} / \mathrm{kg}$, of which $77 \%$ was of phytic

6 origin. Mean phytase activity was $1018 \pm 319$ PU/kg. A genotypic effect on phytase activity

7 was detected amongst 5 varieties studied out of 30. Potential and real applied viscosities were

8 positively correlated and mean values were $3.53 \pm 0.66$ and $2.15 \pm 0.31 \mathrm{ml} / \mathrm{g}$, respectively.

9 3. The efficacy of plant phytase in improving $\mathrm{P}$ availability was assessed in chickens up to 3 10 weeks of age. Growth performance and bone ash concentration were compared in birds given 11 either a maize $(450 \mathrm{~g} / \mathrm{kg})$ and soybean meal $(230 \mathrm{~g} / \mathrm{kg})$ phosphorus deficient diet containing $123.5 \mathrm{~g} \mathrm{P} / \mathrm{kg}$, this basal diet supplemented with 1 or $2 \mathrm{~g} \mathrm{P} / \mathrm{kg}$ as monocalcium phosphate (MCP) 13 or triticale $(450 \mathrm{~g} / \mathrm{kg})$ and soybean meal $(230 \mathrm{~g} / \mathrm{kg})$ diets containing 3.2 to $3.8 \mathrm{~g} \mathrm{P} / \mathrm{kg}$ with no 14 MCP. To achieve graded levels of phytase activity, 4 varieties of triticale, intact or in which 15 phytase was denaturated by heat treatment, were used. Estimated metabolisable energy, 16 protein, amino acids and calcium concentrations were similar in all diets.

17 4. Phytase activity in the triticale-based diets ranged between 135 and $1390 \mathrm{PU} / \mathrm{kg}$. Growth 18 performance and bone ash were responsive to plant phytase and to MCP. Non-linear models 19 of these responses were adjusted with the best fit for bone ash parameters. 250, 500 and 1000 20 PU of plant phytase were estimated to be equivalent to $0.46,0.67$ and $0.81 \mathrm{~g} \mathrm{P}$ as $\mathrm{MCP}$, 21 respectively.

\section{INTRODUCTION}

23 Triticale is a hybrid of wheat and rye that has been proposed as an alternative cereal in animal 24 feeding because of its potential combination of wheat feeding characteristics and rye winter 
1 hardiness and disease resistance (Gatel et al., 1985; Vieira et al., 1995). Several grain

2 constituents play a role in optimum utilisation of this cereal by poultry. Among them, both

3 soluble non-starch-polysaccharides (NSP), mainly arabinoxylans present in the albumen, and

4 available phosphorus $(\mathrm{P})$ are of great impact with regard to the nutritive value of the cereal

5 and to the alimentary strategies to control environmental pollution problems (Carré et al.,

6 1994; Barrier-Guillot et al., 1996b) and are worth consideration in varietal selection

7 programmes. Improvements in nutritional value of triticale for broilers will increase the

8 economical interest in replacing wheat by triticale in broilers (Korver et al., 2004). Protein

9 concentation and its amino acid profile as well as metabolisable energy are key contributors to

10 feeding value. High contents of arabinoxylans should be avoided, because this might increase

11 feed viscosity, reduce digestibility of various components and induce over-consumption of 12 water by birds, which results in aqueous excreta (Carré et al., 2002). In contrast, high $\mathrm{P}$ 13 availability reduces the requirement for supplementing diets with mineral $\mathrm{P}$ leading to lower 14 excretion of this element by the animals.

15 The effect of arabinoxylans on viscosity can be assessed by means of real applied 16 viscosity (RAV) and potential applied viscosity (PAV) which refer to viscosity measured 17 when endogenous xylanases are allowed to act and are inactivated, respectively (Carré et al., 1994; Carré, 2002). In wheat, these parameters are factors of variation in metabolisable 19 energy (Carré et al., 2002). Bouguennec et al. (2000) reported PAV values from 1.6 to 5.1 for 2049 varieties of triticale from the official French catalogue and highlighted that PAV is mainly 21 under genetic control, even if it may also be affected by environmental conditions. Similarly 22 in wheat, RAV and PAV are dependent on the genotype, although RAV, which depends on an 23 enzymatic activity, is affected by an environment $\mathrm{x}$ genotype interaction (Oury et al., 1998). In wheat, variability in $\mathrm{P}$ availability for poultry is mainly related to phytase activity 25 but not to phytic P concentration (Barrier-Guillot et al., 1996b). Moreover, phytase activity 
1 displays a significant genotypic effect in wheat, although it is also influenced by a genotype $\mathrm{x}$

2 environment interaction (Barrier-Guillot et al., 1996a; Oury et al., 1998). Triticale has been

3 reported to display a phytase activity intermediate between those of wheat and rye (770, 460

4 and 5350 phytase units (PU)/kg, respectively according to INRA-AFZ, 2004) but the

5 available studies (Eeckhout and De Paepe, 1994; Nys et al., 1996; Skiba et al., 2004) do not

6 provide information about the actual genotypic variability. Besides, the effectiveness of plant

7 phytase to improve $\mathrm{P}$ availability in chickens has mainly been studied in wheat (Barrier-

8 Guillot et al., 1996b; Potkansky, 2000; Paik, 2003; Juanpere et al., 2004), with little

9 information available for triticale. Almost no information about the potential sparing effect of 10 triticale on the need for mineral $\mathrm{P}$ supplementation is available.

11 The aim of the present study was to evaluate the genotypic variability, in triticale, of 12 several characteristics including viscosity and phytase activity. In addition, the efficacy of 13 plant phytase contained in triticale to reduce the required mineral $\mathrm{P}$ supplementation in diets 14 for chickens was evaluated.

\section{MATERIALS AND METHODS}

\section{Triticale varieties and lines}

17 A total of 30 varieties and selection lines of triticale originating from different areas in Europe 18 and covering a wide range of genotypic variability were selected. They were grown at the 19 INRA research station in Clermont-Ferrand under a single crop management system adapted 20 to the local conditions. The 30 batches were each collected from a single plot (Table 1). In 21 addition, 5e varieties (DI34-2, Trimaran, Aubrac, Capitale and Calao) were chosen for the 22 wide range in phytase activity they displayed. They were each grown on 4 - 6 plots and were 23 used to assess the genotypic effect on phytase activity. Four out of these 5 latter varieties 24 (DI34-2, Trimaran, Aubrac and Calao) were used to assess response of chickens to graded 
1 levels of plant phytase. For this latter study, a mixture in equal proportions of the 4 to 6

2 available sub-batches of each variety was constituted.

Table 1 near here

\section{Broiler experiment}

4 The experiment was conducted under the animal research guidelines of the French Ministry of

5 Agriculture. From hatching till $5 \mathrm{~d}$ of age, 220 male Ross white chicks were placed in plastic-

6 coated cages of two or three birds each and fed on a standard diet covering all nutrient

7 requirements (INRA, 1989). At d 5, chicks were individually weighed after an overnight fast

8 and the 192 chicks closest to the mean weight of $75.7 \pm 1.78 \mathrm{~g}$ were placed in 96 plastic-

9 coated cages, with two birds of similar initial live weight in each. For the subsequent 16-d

10 experiment, chicks were fed on one of 12 experimental diets ( 8 cages per diet). The initial 11 room temperature of $32^{\circ} \mathrm{C}$ was gradually decreased to to 30 and $28^{\circ} \mathrm{C}$ when the chicks 12 reached the ages of 2 and $14 \mathrm{~d}$, respectively. During the first $2 \mathrm{~d}$, birds were kept under $24 \mathrm{~h}$ 13 light a d and $23 \mathrm{~h}$ light per $\mathrm{d}$ thereafter. Birds had free access to water throughout the 14 experiment. After a 12 to 14-h fast, each chicken was weighed and killed and its right 15 tibiotarsus was collected. Feed consumption was recorded per cage for the 16-d experimental 16 period. Feed conversion ratio (FCR) was calculated as the ratio of feed intake to weight gain 17 over the 16-d experimental period.

18 Twelve diets were formulated to meet all nutrient requirements of the birds (INRA, 19 1989), except available P. Feedstuffs were ground in a hammer mill fitted with a $2.5 \mathrm{~mm}$ 20 screen prior to incorporation in the diet. Mixed diets were pelleted without steam addition. 21 Damage to plant phytase was not expected, as outlet temperature did not exceed $50^{\circ} \mathrm{C}$. The 22 three first diets, with a phytase activity below the detection limit of $50 \mathrm{PU} / \mathrm{kg}$, were based on 23 maize $(450 \mathrm{~g} / \mathrm{kg})$ and soybean meal $(230 \mathrm{~g} / \mathrm{kg})$ and contained graded levels of monocalcium 24 phosphate (MCP, 0, 1 and $2 \mathrm{~g} / \mathrm{kg}$ in diets 1, 2 and 3, respectively) (Table 2). The basal diet 25 without any inorganic phosphorus contained 3,5 $\mathrm{g} \mathrm{P} / \mathrm{kg}$ and was deficient in non-phytic 
1 phosphorus compared to the requirement for growing chickens. Diets 4 to 12 , did not contain

2 any maize but $450 \mathrm{~g} / \mathrm{kg}$ of triticale. No MCP was added. In order to achieve graded levels of

3 phytase activity, four different genotypes of triticale (DI34-2, Trimaran, Aubrac and Calao),

4 raw or heat-treated, were introduced in the diets 4 to 7 and 8 to 11 , respectively. A mixture of

5 raw $(200 \mathrm{~g} / \mathrm{kg})$ and heat-treated Calao $(250 \mathrm{~g} / \mathrm{kg})$ was introduced in diet 12 . Heat treatment,

6 which aimed at reducing phytase activity, consisted in two successive heatings in a

7 microwave oven at $600 \mathrm{~W}$ for 2 minutes. Measured phytase activity in the raw triticale-based

8 diets and in the heat-treated triticale-based diets was 620 to $1390 \mathrm{PU} / \mathrm{kg}$ and 135 to 180

$9 \mathrm{PU} / \mathrm{kg}$, respectively. It was $645 \mathrm{PU} / \mathrm{kg}$ in the diet containing the mixture of raw and heated

10 Calao. Maize starch, wheat straw, soy isolate, vegetable oil, calcium carbonate and DL-

11 methionine were used to balance the diets so that estimates of metabolisable energy, protein,

12 lysine, sulphur amino acids, phytic $\mathrm{P}$ and $\mathrm{Ca}$ concentrations were similar in maize-based diets

13 and in triticale-based diets (INRA, 1989). Moreover, the varieties of triticale were chosen so

14 that dietary RAV remained below $1.40 \mathrm{mlL} / \mathrm{g}$ to ensure a limited effect of this parameter on

15 dietary metabolisable energy (Maisonnier et al., 2001). At the end, the 12 diets provided

16 similar and adequate amounts of nutrients for chicks except available P (INRA, 1989).

Table 2

near here

\section{Sampling and analyses}

18 Analyses were performed in duplicate or in triplicate. Thousand grain weight (TGW) was 19 assessed by passing $200 \mathrm{~g}$ of fresh grain through an automated Decca seed counter and 20 adjusting weights to $15 \%$ moisture content. Specific weight (SW) was measured by means of 21 a Nilema apparatus (Tripette et Renaud, France). The Hagberg falling number (HFN) was 22 assessed by means of a Falling Number apparatus type 1400 (Falling Number AB, Sweden) 23 after grinding with a Falling Number mill type KT120 (Falling Number AB, Sweden). 24 Samples of triticale and diets were ground to pass through a $0.5 \mathrm{~mm}$ screen and stored at $4^{\circ} \mathrm{C}$ 25 prior to the other analyses. $\mathrm{N}$ was determined by the Kjeldahl method according to the French 
1 standard AFNOR (NFV 18-100) using a Kjelfoss apparatus (A/S N Foss Electric, Denmark).

2 Dry matter (DM) was measured by drying at $103^{\circ} \mathrm{C}$ until constant weight. $\mathrm{P}$ was analysed by

3 means of the vanadate colorimetric method according to the AFNOR method (NFV 18-106).

4 Phytic P was determined by ion-pair HPLC (Column $\mathrm{C}_{18}$, Hypersyl C 18-5 $\mu \mathrm{m} 200$ x 2 mm,

5 Interchim) after acidic extraction and anionic exchange purification according to the method

6 developed by Sandberg and Adherrine (1986) and modified by Lehrfeld (1989). Phytase

7 activity (PA) was measured colorimetrically after incubation in a sodium phytate solution

8 (Engelen et al., 1994). One phytase unit (PU) is the amount of enzyme that liberates $1 \mu \mathrm{mol}$

9 per minute of inorganic $\mathrm{P}$ from $5.1 \mathrm{mmol} / 1$ solution of sodium phytate, at $\mathrm{pH} 5.5$ and $37^{\circ} \mathrm{C}$.

10 Prior to viscosity determination, extraction $\left(\mathrm{pH}=4.5\right.$, temperature $\left.=19-23^{\circ} \mathrm{C}\right)$ was performed

11 with or without pre-treatment in hot ethanol: water (80: 20). RAV and PAV refer to viscosity 12 measured when endogenous xylanases were allowed to act and were inactivated by treatment 13 of the sample, respectively. The viscosity data were divided by the viscosity of the buffer, 14 which gave relative viscosities (Vr), transformed into natural logarithm and then divided by 15 the concentration $(\mathrm{g} / \mathrm{mL})$ of the plant material in the buffer extraction volume. The results 16 “( $\mathrm{Ln}(\mathrm{Vr})) /(\mathrm{g} / \mathrm{ml}) ”$ were expressed as $\mathrm{ml} / \mathrm{g}$ (Carré et al., 1994; Carré, 2002).

17 Tibiotarsi were pooled per cage. They were cleaned of all soft tissues, defatted (24 18 hours in ether), dried $\left(105^{\circ} \mathrm{C}\right.$ for 12 hours $)$ and weighed. Thereafter, they were ashed at $550^{\circ} \mathrm{C}$ 19 for $14 \mathrm{~h}$ in a muffle furnace and weighed. Ash concentration was calculated on a fat-free dry 20 matter (FF DM) basis.

\section{Statistical analyses}

22 Statistical analysis of data was performed by means of the GLM procedure of the Statistical 23 Analysis Systems software package version 8.1 (SAS, 1990). Correlation coefficients $(r)$ 24 between physical and analytical characteristics of the 30 batches of triticale were calculated. 25 The effect of the variety on phytase activity was assessed by an analysis of variance using the 
1 plot as the experimental unit, followed by a comparison of means. The chickens' responses

2 were analysed using the cage as the experimental unit. Data were first submitted to an

3 analysis of variance with the diet as main factor, followed by a comparison of means.

4 Polynomial regression of the indicators of performance and of bone mineralisation was used

5 to determine the presence of linear and quadratic effects of mineral $\mathrm{P}$ added in the diet and of

6 dietary phytase activity. Effects were considered significant when $P<0.05$.

Non-linear (NLIN procedure of SAS) functions were fitted to the response of performance and bone FF DM and ash to dietary $\mathrm{P}$ as $\mathrm{MCP}$ and phytase activity, using treatment means. Exponential models were chosen to describe the response to phytase and linear or exponential models were chosen to describe the response to mineral $\mathrm{P}$, according to the results obtained by polynomial regression. The exponential model was chosen because it was extensively used to describe the effect of microbial phytase on P availability (Kornegay et al., 1996; Kornegay, 2001). The model was $\mathrm{Y}=\mathrm{a}+\mathrm{b}\left(1-\mathrm{e}^{-1 \mathrm{MinP}}\right)+\mathrm{c}\left(1-\mathrm{e}^{-\mathrm{kPhyt}}\right)$ or $\mathrm{Y}=\mathrm{a}$ $+\mathrm{b} \operatorname{MinP}+\mathrm{c}\left(1-\mathrm{e}^{-\mathrm{k} \text { Phyt }}\right)$ with $\mathrm{Y}=$ response measurement, MinP $=\mathrm{P}$ added as MCP $(\mathrm{g} / \mathrm{kg}$ diet $),$ Phyt $=$ phytase activity $(\mathrm{PU} / \mathrm{kg}$ diet $)$.

The coefficient of determination $\left(R^{2}\right)$ of each equation generated was calculated as the square of the correlation coefficient between predicted and observed individual values. An equivalency value of mineral $\mathrm{P}$ as $\mathrm{MCP}(\mathrm{g})$ for plant phytase (PU) was calculated by setting equal the terms corresponding to mineral $\mathrm{P}$ and phytase activity.

\section{RESULTS AND DISCUSSION}

\section{Physical and chemical characteristics of the 30 batches of triticale}

Physical and chemical characteristics of the 30 batches of triticale are presented in Table 1. Phytase activity and especially HFN displayed the highest degree of variation, with coefficients of variation (CV) of 31 and $49 \%$, respectively. PAV and RAV exhibited a CV of 15-20\%. Phytic P displayed a CV of similar order, although with only 11 measurements 
1 performed. The other parameters (TGW, $\mathrm{N}$ and total $\mathrm{P}$ ) had lower amplitude of variation (CV

$27-10 \%$ ). This amplitude of variation represents genotypic variability since all the varieties

3 were grown under similar conditions.

4 Total $\mathrm{P}$ concentration in the 30 batches of triticale ranged between 2.06 and $3.57 \mathrm{~g} / \mathrm{kg}$ with a 5 mean of $2.86 \pm 0.31 \mathrm{~g} / \mathrm{kg}$. This average P concentration was slightly below the values of $3.7 \pm$

$6 \quad 0.2$ and $3.9 \pm 0.1 \mathrm{~g} \mathrm{P} / \mathrm{kg}$ previously observed by Eeckhout and De Paepe (1994) and Skiba et

7 al. (2004) when analysing 6 and 4 varieties of triticale, respectively. Phytic P was measured 8 in only 11 out of the 30 batches and ranged between 1.50 and $2.62 \mathrm{~g} / \mathrm{kg}$, with a mean of 2.18 $9 \pm 0.40 \mathrm{~g} / \mathrm{kg}$. These values compare with the $2.5 \pm 0.2$ and $2.4 \pm 0.2 \mathrm{~g}$ phytic $\mathrm{P} / \mathrm{kg}$ reported in 10 the two aforementioned studies. As previously observed in wheat (Barrier-Guillot et al., 11 1996a; Viveros et al., 2000; Kim et al., 2002), P and phytic P were positively correlated $(r=$ $120.60, P<0.05)$ (Table 3). However, the low value of $r$ hampers a reliable prediction of phytate $13 \mathrm{P}$ from total $\mathrm{P}$. In the current study, $77 \%$ of $\mathrm{P}$ was, on average, of phytic origin. This is quite 14 a high proportion compared with the 67 and 61\% reported by Eeckhout and De Paepe (1994) 15 and Skiba et al. (2004), which may be a consequence of the lower total P observed in the 16 current study. P and phytic P concentrations in wheat are influenced by crop management, 17 especially $\mathrm{N}$ and $\mathrm{P}$ fertilisation (Barrier-Guillot et al., 1996a; Oury et al., 1998). 18 Consequently, the current results may have been influenced by the conditions under which 19 triticale was grown.

Table 3 near here 20 Phytase activity measured in the 30 batches of triticale ranged between 447 and 1843 $21 \mathrm{PU} / \mathrm{kg}$, with a mean value of $1018 \pm 319 \mathrm{PU} / \mathrm{kg}$. As expected, these values are intermediate 22 between the phytase activities reported in wheat and in rye (460 and $5350 \mathrm{PU} / \mathrm{kg}$, according to 23 INRA-AFZ, 2004), although they are closer to those of wheat. These values are below the $24 \quad 1688 \pm 227$ and $1784 \pm 386$ PU/kg published by Eeckhout and De Paepe (1994) and Skiba et 25 al. (2004), respectively, but compare with the $1190 \pm 52 \mathrm{PU} / \mathrm{kg}$ measured by Nys et al. (1996) 
1 in 5 batches of triticale. These differences may originate from the huge inter-laboratory

2 variability in phytase activity determination mentioned by Tran and Skiba (2005), even when

3 similar analytical methodologies are implemented. Phytase activity determination might be

4 sensitive to the condition under which batches are stored prior to analysis (temperature,

5 duration of storage if the gain is ground) (Nys et al., 1996) and to the way phytase is extracted

6 before analysis of the liberated inorganic phosphates (Greiner and Egli, 2003).

$7 \quad$ Phytase activity measured in each of the 5 varieties of triticale grown on 4 to 6 plots

8 (Table 4) was 20 to $48 \%$ higher than the value previously obtained on the single batch of the

9 same variety (Table 1). Nevertheless, the varieties were similarly ranked in the two sets of 10 data, with a coefficient of correlation of $0.95(P<0.05, \mathrm{n}=5)$. The origin of this systematic 11 difference is not clear but it may be ascribable to the interaction between the grinding of the 12 samples before analysis and the duration of their storage (Nys et al., 1996). Phytase activity 13 differed $(P<0.01)$ between varieties. In Calao, Capitale, Aubrac and Trimaran, it exceeded by $14112,79,41$ and 30\%, respectively, the value of $1012 \mathrm{PU} / \mathrm{kg}$ in DI34-2. This genotypic effect 15 on phytase activity was previously reported in wheat (Barrier-Guillot et al., 1996a; Kim et al., 16 2002; Oury et al., 1998; Tran and Skiba, 2005). However, Oury et al. (1998) detected a strong 17 genotype $\mathrm{x}$ environment interaction in the phytase activity of wheat. This interaction, which 18 may also exist in triticale, was not investigated in the current study. Phytase activity was 19 negatively correlated $(P<0.05)$ with SW and HFN, which is consistent with the fact that low 20 HFN (and possibly SW) might be linked with the stimulation of enzymatic activity in the 21 grain at germination as observed for amylase (Niziolek et al., 1994). As previously reported in 22 wheat (Eeckhout et de Paepe, 1994; Barrier-Guillot et al., 1996a) no relationship between 23 phytase activity and $\mathrm{P}$ or phytic $\mathrm{P}$ could be detected. In contrast, Viveros et al. (2000) found a 24 positive correlation between phytase activity and $\mathrm{P}$ in wheat; however, they were not able to 25 predict phytate $\mathrm{P}$ or phytase activity reliably from total $\mathrm{P}$.

Table 4 near here 
PAV and RAV ranged between 2.35 and $4.65 \mathrm{ml} / \mathrm{g}$ and 1.71 and $2.86 \mathrm{ml} / \mathrm{g}$,

2 respectively, with average values of $3.53 \pm 0.66$ and $2.15 \pm 0.31 \mathrm{~mL} / \mathrm{g}$, respectively (Table 1).

3 The PAV values are in the range of those reported by Bouguennec et al. (2000) in triticale.

4 They are between those observed in rye (PAV $=28 \mathrm{~mL} / \mathrm{g}$, Carré et al., 1994) and wheat (PAV $5=2.9 \mathrm{~mL} / \mathrm{g}$, Oury et al., 1998; Carré et al., 2002), although they are closer to those of wheat.

6 As previously reported (Oury et al., 1998), PAV and RAV were positively correlated ( $r=$ $7 \quad 0.43, P<0.05)$ with each other but not with any other characteristic.

Nitrogen concentration in the 30 varieties of triticale ranged between 14.1 and $18.1 \mathrm{~g}$

$9 \mathrm{~N} / \mathrm{kg}$ (Table 1), corresponding to a mean level of protein of $101 \pm 8.8 \mathrm{~g} / \mathrm{kg}$ with a range of 88

10 to $113 \mathrm{~g} / \mathrm{kg}$. This crude protein level is slightly lower than those observed in 8 Australian 11 cultivars (range 101-135 g/kg; Johnson and Eason, 1988) or that analysed by Vieira et al. $12(1995)(129 \mathrm{~g} / \mathrm{kg})$ but is in agreement with levels observed by other authors: $72-110 \mathrm{~g} / \mathrm{kg}$ 13 (Zacarias et al., 1982), $93 \mathrm{~g} / \mathrm{kg}$ (Proodfoot and Hulan, 1988).

\section{Triticale phosphorus availability in broilers}

15 The microwave treatment applied to triticale was effective in reducing phytase activity, which 16 was reduced after treatment by $85-90 \%$, down to $142,156,126,127 \mathrm{PU} / \mathrm{kg}$ in DI34-2, 17 Trimaran, Aubrac and Calao, respectively. Phytase activity measured in diets exceeded the 18 value expected from measurements performed on the batches of triticale, especially at low 19 levels of phytase activity (Table 2). However, phytase activity measured in the batches of 20 triticale and in the diets were highly correlated $(r=0.99, P<0.001, \mathrm{n}=8)$. RAV in non-heated 21 triticale-based diets was 10 to $23 \%$ lower than in heated triticale-based diets, suggesting that 22 heat treatment reduced xylanase activity. However, it remained below $1.40 \mathrm{ml} / \mathrm{g}$, even in 23 heated triticale-based diets. In the current study, heat treatment was considered to have no 24 effect on phytate concentration because phytates present in cereals are very stable to heating 25 (Reddy et al., 1989; Juanpere et al., 2004). 
Performance and bone characteristics of birds are presented in Table 5. Five birds fed

2 the maize based diet without MCP (diet 1) died before the end of the experiment, explaining

3 the removal of data from three cages. A high mortality level has previously been observed in

4 chicks fed on maize based diets without supplemented mineral P (Kornegay et al., 1996; Paik,

5 2003).

Table 5 near here

6

7

For all the variables studied, significant differences $(P<0.001)$ among diets were detected. Chicks given the maize-based diets without phosphate and supplemented with $2 \mathrm{~g} \mathrm{P}$ as MCP displayed the lowest performance and the highest bone characteristics. The linear response of bone ash to graded level of inorganic phosphorus demonstrates that the chicks fed on negative control diet were deficient in phosphorus. Performance and bone characteristics in chickens given the raw triticale-based diets did not differ $(P>0.05)$ from those of chickens given the maize-based diet supplemented with $1 \mathrm{~g} \mathrm{P}$ as $\mathrm{MCP} / \mathrm{kg}$, except for bone ash concentration in the Trimaran-based diet, which was lower. Overall, bone characteristics and final weight of chickens given the heated triticale-based diets were intermediate between those of chickens given the unsupplemented maize-based diet and the raw triticale-based diets. Except for the heated DI-34-2-based diet, feed intake in chicks given the heated triticale-based diets did not differ from that in chicks fed the unsupplemented maize-based diet, while their FCR did not differ from that in chicks fed the raw triticale-based diets. Chickens given the maize-based diet supplemented with $2 \mathrm{~g} \mathrm{P}$ as $\mathrm{MCP} / \mathrm{kg}$ ingested 2.1 times more feed than chickens given the maize-based diet without MCP. Feed intake increased linearly $(P<0.001)$ and quadratically $(P<0.05$ and $P<0.001$, respectively) with supplemental $\mathrm{P}$ supply and with the dietary level of phytase. By the end of the experiment, birds fed on the maize-based diet supplemented with $2 \mathrm{~g} \mathrm{P}$ as $\mathrm{MCP} / \mathrm{kg}$ were 2.2 times heavier than birds given the maize-based diet without added P. Final weight increased linearly $(P<0.001)$ and quadratically $(P<0.01$ and $P<0.001$, respectively) with $\mathrm{P}$ addition and with dietary phytase 
1 activity (Figure). FCR decreased linearly and quadratically with added $\mathrm{P}(P<0.01$ and $2 \quad P<0.05$, respectively) and dietary phytase activity $(P<0.001$ and $P<0.01$, respectively). FCR

3 was decreased by $30 \%$ by supplementing the maize-based diet with $1 \mathrm{~g} \mathrm{P}$ as MCP, but no

4 further improvement was achieved with $2 \mathrm{~g} \mathrm{P}$ as MCP. Chickens given the heated triticale5 based diets, still containing some phytase (135 to 200 PU), displayed a FCR 25\% lower than 6 chicks on the unsupplemented maize-based diet with no further improvement with raw 7 triticale-based diets. Improvements in weight gain, feed intake, and FCR with increased available $\mathrm{P}$ 9 provision through $\mathrm{P}$ or phytase supplementation of low $\mathrm{P}$ diets have been previously reported (Broz et al., 1994; Kornegay et al., 1996; Sebastian et al., 1996a and b; Paik, 2003). From a 11 literature review including 298 observations from 18 literature references, Lescoat et al. 12 (2005) established an exponential relationship between body weight gain of chickens 13 slaughtered at 21 to $24 \mathrm{~d}$ and $\mathrm{P}$ intake. The two-fold increase in final weight with the addition 14 of $2 \mathrm{~g} \mathrm{P}$ as MCP in the maize-based diet fits well with the relationship established by these 15 authors. Increased weight gain with supplemental P may have resulted not only from an 16 increase in feed intake but also from a specific effect of $\mathrm{P}$ on growth. A specific effect of $\mathrm{P}$ is 17 expected in the chick because of the important role of this element in the formation of the skeletal system and in body metabolism (e.g. nucleic acids, high-energy compounds and 19 various enzymatic reactions), and because of the fast rate of chick growth and its low capacity 20 of P storage (Kornegay et al., 1996).

Bone FF DM followed a trend very similar to final weight $(r=0.90, P<0.001, \mathrm{n}=90)$ 22 with an increase in bone FF DM by 2.9 times when $2 \mathrm{~g}$ of $\mathrm{P}$ were added to the maize based 23 diet. Bone FF DM responded linearly to $\mathrm{P}$ added $(P<0.001)$ and linearly $(P<0.001)$ and 24 quadratically $(P<0.01)$ to phytase activity. The amplitude of the response of bone ash $(\mathrm{g})$ was 25 a 5.1-fold increase when $2 \mathrm{~g}$ of $\mathrm{P}$ were added to the maize based diet. Bone ash ( $\mathrm{g}$ and relative 
1 to FF DM) increased linearly with added $P$ and with phytase activity $(P<0.001)$ and

2 quadratically with phytase activity $(P<0.001)$. The linearity and the higher amplitude of the

3 response of bone ash to dietary $\mathrm{P}$ compared to body weight gain indicates the ability of bone

4 to incorporate $\mathrm{P}$ beyond the dietary supply needed to maximize weight gain (Figure). Relying

5 on 316 observations collected in 15 literature references, Lescoat et al. (2005) established that

6 bone ash concentration in chickens reached a plateau when 250-300 mg total P were ingested

7 per $\mathrm{d}$, a value that is higher than the $220 \mathrm{mg}$ total $\mathrm{P}$ daily ingested by the chickens fed on the

8 maize diet supplemented with $2 \mathrm{~g} \mathrm{P}$ as $\mathrm{MCP}$. Moreover, the increase in bone ash

9 concentration fits well with the range of variation observed by these authors for similar

10 dietary P supply. The improvement in bone ash in chickens fed on triticale diets indicates that

11 plant phytase was effective in releasing $\mathrm{P}$ from the phytate-mineral complex. The maximum

12 responses appeared to occur at around $600 \mathrm{PU}$ plant phytase/kg diet whatever the indicator.

13 Before equivalency values of plant phytase for $\mathrm{P}$ as MCP can be estimated, the

14 question arises whether responses of performance and bone characteristics observed in the 15 current study can be ascribed solely to the improvement in available $\mathrm{P}$ supply by means of $\mathrm{P}$ 16 as MCP in maize-based diets and by means of increased phytase activity in triticale-based 17 diets. In the control diet, maize was preferred to a mixture of heated triticale batches to avoid 18 any side effect due to heating other than lowering phytase activity and because maize is the 19 reference cereal used when evaluating any source of phosphorus in the literature. The results 20 of the current study cannot be used to compare the relative efficiency of maize and triticale 21 for chick performance. Nevertheless, maize- and triticale-based diets provided sufficients 22 amounts of all nutrients to fulfill the requirement of growing chicks up to 3 weeks of age, 23 except for P (INRA, 1989). Particularly, because all diets were balanced for Ca, there is a 24 very high probability that the response of bone ash concentration was related to available $\mathrm{P}$ 25 supply rather than to any other dietary parameter. The magnitude of variation in performance 
1 in the current study is very large compared with the slight decrease in performance reported

2 when maize is replaced by wheat (Singh et al., 2003) or by triticale (Proudfoot and Hulan,

3 1988) in isocaloric, isonitrogenous, iso-Ca and iso-P diets fed to chickens. The former authors

4 ascribe this depressed performance to the presence of arabinoxylans in wheat. In the current

5 study, RAV in triticale-based diets was not greater than $1.40 \mathrm{ml} / \mathrm{g}$, and, according to

6 Maisonnier et al. (2001), such concentrations of RAV do not influence performance in 7 chicks.

11 determination of 0.77 to 0.89 . All the indicators used were sensitive to plant phytase or MCP 12 supply, but the fit was better for bone ash than for the other parameters. Moreover, the actual 13 weight of bone ash displayed the highest $R^{2}$ for both the non-linear and polynomial 14 adjustments. Other authors have concluded that bone ash weight is the most sensitive 15 indicator to assess phytase efficacy in chickens (Zhang et al., 2000; Hall et al., 2003). 16 Random variability in the organic matrix left after water and lipid removal may be responsible 17 for the decreased $R^{2}$ value for ash expressed on a fat-free dry matter basis (Hall et al., 2003). 18 Based on bone ash parameters, increase in plant phytase activity from 0 to 250 PU was 19 estimated to be equivalent to $0.46-0.47 \mathrm{~g} \mathrm{P}$ as MCP. Between 250 and $500 \mathrm{PU}, 250 \mathrm{PU}$ were 20 estimated to allow the release of an amount of $\mathrm{P}$ equivalent to $0.20-0.22 \mathrm{~g}$ of $\mathrm{P}$ as MCP. 21 Between 500 and $1000 \mathrm{PU}$, an equivalency of $0.12-0.15 \mathrm{~g} \mathrm{P}$ as MCP for $500 \mathrm{PU}$ was 22 obtained.

Table 6 near here

23 The equivalency values are not easy to compare with literature data because the 24 efficacy of phytase has been shown to depend on several parameters including the dietary 25 non-phytic $\mathrm{P}$ and $\mathrm{Ca}$ concentrations. These equivalency values may be relatively high because 
1 the triticale-based diets were not supplemented with P. Kornegay et al. (1996) demonstrated

2 that, probably because of an available $\mathrm{P}$ supply closer to the requirement, the equivalency

3 values decrease when the dietary non-phytate $\mathrm{P}$ concentration increases. On the contrary, the

4 wide Ca:P ratio in the current study, greater than $2.8: 1$, may have reduced the efficacy of

5 phytase in releasing phytate $\mathrm{P}$. Increasing the $\mathrm{Ca}: \mathrm{P}$ ratio in poultry diets was reported to

6 decrease the efficacy of microbial phytase (Schoner et al., 1993; Qian et al., 1996; Sebastian

7 et al., 1996b), with the optimum responses to phytase obtained at a Ca:P ratio as low as 1.1:1.

8 In accordance with our results, Paik (2003) observed that 650 PU of plant phytase

9 achieved by the addition of wheat and wheat bran in a maize-soybean meal-based diet were 10 equivalent to at least $1 \mathrm{~g} \mathrm{P}$ as tricalcium phosphate in terms of growth performance and 11 mineral retention in chickens up to $35 \mathrm{~d}$. Similarly, an equivalency of $0.65-1 \mathrm{~g} \mathrm{P}$ as MCP for 12500 PU was reported by Frapin (1996) when evaluating plant phytase efficiency from various 13 wheat varieties. At variance with our results, Juanpere et al. (2004) did not observe any effect 14 of around 150 units of phytase from barley on performance and toe ash concentration in 15 chicks. This absence of efficacy of plant phytase may be ascribable to a higher non-phytate $\mathrm{P}$ 16 concentration than in the current study. From literature data, Kornegay et al. (2001) estimated 17 that $500 \mathrm{PU}$ of microbial phytase (3-phytase) were equivalent to $0.8 \mathrm{~g} \mathrm{P}$ as MCP for $500 \mathrm{PU}$ 18 in terms of mineral retention in broilers. This higher figure may originate from the lower 19 efficacy of plant phytase compared to microbial 3-phytase demonstrated in broilers (Frapin, 20 1996; Potkansky, 2000) and in pigs (Zimmermann et al., 2002). The activity of plant phytase 21 decreases rapidly when the $\mathrm{pH}$ decreases below the optimum $\mathrm{pH}$ of 5.0-5.5, whereas the 322 phytase still displays an activity of $60 \%$ of the optimum at $\mathrm{pH} 2$ (Eeckhout and De Paepe, 23 1996). Plant phytase would be 40 to $80 \%$ less efficient in releasing $\mathrm{P}$ from phytates in vivo 24 than 3-phytase due to the low pH in the stomach of pigs and gizzard of poultry (Frapin, 1996; 25 Potkansky, 2000; Zimmermann et al., 2002). The acidic $\mathrm{pH}$ of the gizzard inactivates plant 
1 phytase in contrast to protected microbial phytase and consequently plant phytase activity is

2 limited to the crop (Frapin, 1996). Moreover, plant phytase may be more sensitive to the

3 presence of pepsin than 3-phytase (Rapp et al., 2001).

The present study confirmed the usefulness of the introduction of triticale in chickens'

5 diets to reduce $\mathrm{P}$ emission and to limit environmental pollution, $500 \mathrm{PU}$ of plant phytase

6 being equivalent to $0.66-0.69 \mathrm{~g} \mathrm{P}$ as MCP. Accounting for the genotypic variability of phytase

7 activity in triticale (447 to $1843 \mathrm{PU} / \mathrm{kg}$ ), a diet containing $450 \mathrm{~g} / \mathrm{kg}$ triticale may display a

8 phytase activity of 201 to $829 \mathrm{PU} / \mathrm{kg}$, provided plant phytase is not denaturated during feed

9 processing. In such a diet, $\mathrm{P}$ supplementation as MCP may be reduced by 0.4 to $0.8 \mathrm{~g} / \mathrm{kg}$,

10 compared to a low phytase diet, such as a maize-based diet.

\section{REFERENCES}

BARRIER-GUILLOT, B., CASADO, P., MAUPETIT, P., JONDREVILLE, C. \& GATEL, F. (1996a) Wheat phosphorus availability: 1 - In vitro study; factors affecting endogenous phytasic activity and phytic phosphorus content Journal of the Science of Food and Agriculture, 70: 62-68.

BARRIER-GUILLOT, B., CASADO, P., MAUPETIT, P., JONDREVILLE, C. \& GATEL, F. (1996b) Wheat P availability: 2 - In vivo study in broilers and pigs; relationship with endogenous phytasic activity and phytic phosphorus content in wheat. Journal of the Science of Food and Agriculture, 70: 69-74.

BOUGUENNEC, A., OURY, F.X. \& JESTIN, L. (2000) Viscosity related to arabinoxylans in triticale: genetic and environmental variation in France. Vorträge für Pflanzenzüchtung, 49: $161-169$.

BROZ, J., OLDAlE, P., PERRINVOLTZ, A. H., RYCHEN, G., SCHUlZE, J. \& SIMOES NUNES, C. (1994) Effects of supplemental phytase on performance and phosphorus 
1 utilisation in broiler chickens fed a low phosphorus diet without addition of inorganic 2 phosphates. British Poultry Science, 35: 273-280.

3 CARRÉ, B. (2002) Carbohydrate chemistry of the feedstuffs used for poultry, in: McNAB, B. 4

6 CARRE, B., GOMEZ, J., MELCION, J.P. \& GIBOULOT, B. (1994) La viscosité des aliments destinés à l'aviculture. Utilisation pour prédire la consommation et l'excrétion d'eau. INRA Productions Animales, 7: 369-379.

9 CARRÉ, B., IDI, A., MAISONNIER, S., MELCION, J. P., OURY, F. X., GOMEZ, J. \&

ENGELEN, A.J., VAN DER HEEFT, F.C., RANDSDORP, P.H.G. \& SMIT, E.L.C. (1994) Simple and rapid determination of phytase activity. Journal of AOAC International, 77: PLUCHARD, P. (2002) Relationships between digestibilities of food components and characteristics of wheat (Triticum aestivum) introduced as the only cereal source in a broiler chicken diet. British Poultry Science 43: 404-415.

EECKHOUT, W. \& DE PAEPE, M. (1994) Total phosphorus, phytate-phosphorus and phytase activity in plant feedstuffs. Animal Feed Science and Technology, 47: 19-29.

EECKHOUT, W. \& DE PAEPE, M. (1996) In vitro and in vivo comparison of microbial and plant phytase, in: COELHO, M.B. \& KORNEGAY, E.T. (Eds) Phytase in Animal Nutrition and Waste Management, pp 237-240 (Mount Olive, NJ, BASF corporation). 760-764.

FRAPIN, D. (1996) Valorisation du phosphore phytique végetal chez l'oiseau : intérêt et mode d'action des phytases végétales et microbiennes. Thèse de l'école nationale supérieure agronomique de Rennes, $134 \mathrm{p}$. 
1 GATEL, F., LAVOREL, O., FEKETE, J., GROSJEAN, F. \& CASTAING, J. (1985) Feeding

2 value of triticale for monogastrics: weaned piglets, growing finishing pigs and broilers, in: BERNARD, M. \& BERNARD, S. (Eds) Genetics and Breeding of Triticale, pp 659-670 (Paris, France, INRA).

GREINER, R. \& EGLI, I. (2003) Determination of the activity of acidic phytase-degrading enzymes in cereal seeds. Journal of Agricultural and Food Chemistry, 51: 847-850.

HAll, L. E., Shirley, R. B., BAKAlli, R. I., AGgrey, S. E., PESTI, G. M. \& EDWARDS, H. M. (2003) Power of two methods for the estimation of bone ash of broilers. Poultry Science, 82:414-418.

INRA-AFZ (2004) Tables of composition and nutritional value of feed materials, in:

SAUVANT, D., PEREZ, J.M. \& TRAN, G. (Eds) 304 pp (Paris, France, Institut National de 14 la Recherche Agronomique, Association Française de Zootechnie).

15 JOHNSON, R. \& EASON, P. (1988) Evaluation of triticale for use in diets for meat-type 16 chickens. Journal of the Science of Food and Agriculture, 42: 95-108.

JUANPERE, J., PEREZ-VENDRELL, A. M. \& BRUFAU, J. (2004) Effect of microbial

KIM, J. C., MUllaN, B. P., SElle, P. H. \& PLUSKE, J. R. (2002) Levels of total 21 phosphorus, phytate-phosphorus, and phytase activity in three varieties of Western phytase on broilers fed barley-based diets in the presence or not of endogenous phytase. Animal Feed Science and Technology, 115: 265-279. Australian wheats in response to growing region, growing season, and storage. Australian Journal of Agricultural Research, 53: 1361-1366. 
1 KORNEGAY, E. T. (2001) Digestion of phosphorus and other nutrients: the role of phytases

2 and factors influencing their activity, in : Bedford, M. R. \& Partridge, G. G. (Eds)

3 Enzymes in Farm Animal Nutrition, pp 237-271 (Wallingford, CAB International).

4 KORNEGAY, E. T., DENBOW, D., Yi, Z. \& RAVINDRAN, V. (1996) Response of broilers 5 852.

8 KORVER, D.R., ZUIDHOF, M.J. \& LAWES, K.R. (2004) Performance characteristics and economic comparison of broiler chickens fed wheat- and triticale-based diets. Poultry Science 83: 716-725.

LEHRFELD, J. (1989) High performance liquid chromatography analysis of phytic acid on a pH-stable, macroporous polymer column. Cereal Chemistry, 66: 510-515.

14 l'apport de phosphore. INRA Productions Animales, 18: 193-201.

15 MAISONNIER, S., GOMEZ, J., CARRE, B. (2001) Nutrient digestibility and intestinal 16 viscosities in broiler chickens fed on wheat diets, as compared to maize diets with added 17 guar gum. British Poultry Science, 42: 102-110.

NIZIOLEK, S., BARTOSZEWICZ, K. \& KACZKOWSKI, J. (1994) Some hydrolases and their substrates occurring in initial period of germination in triticale grains of various preharvest sprouting resistance. Acta Physiologiae Plantarum, 16: 171-176.

21 NYS, Y., FRAPIN, D. \& POINTILLART, A. (1996) Occurrence of phytase in plants, animals and microorganisms, in: COELHO, M.B. \& KORNEGAY, E.T. (Eds) Phytase in Animal Nutrition and Waste Management, pp 213-236 (Mount Olive, NJ, BASF corporation). 
1 OURY, F.X., CARRE, B., PLUCHARD, P., BERARD, P., NYS, Y. \& LECLERCQ, B.

2 (1998) Genetic variability and stability of poultry feeding related characters in wheat, in

3 relation to environmental variation. Agronomie, 18: 139-150.

4 PAIK, I. (2003) Application of phytase, microbial or plant origin, to reduce P excretion in poultry production. Asian-Australasian Journal of Animal Sciences, 16:124-135.

POTKANSKY, A. (2000) The comparison of plant and microbial phytases in the feeding, in: Grela (Ed) Proceedings of the International Symposium on Phytase in Animal Nutrition, pp 21-27 (Lublin).

QIAN, H., KORNEGAY, E. T. \& DENBOW, D. M. (1996) Phosphorus equivalence of microbial phytase in turkey diets as influenced by calcium to phosphorus ratios and phosphorus levels. Poultry Science, 75: 69-81.

RAPP, C., LANTZSCH, H. J. \& DROCHNER, W. (2001) Hydrolysis of phytic acid by intrinsic plant or supplemented microbial phytase (Aspergillus niger) in the stomach and small intestine of minipigs fitted with re-entrant cannulas. 2. Phytase activity. Journal of Animal Physiology and Animal Nutrition, 85: 414-419.

REDDY, N.K., PIERSON, M.D., SATHE, S.K. \& SALUNKHE, D.K., 1989. Phytates in

SANDBERG, A.S. \& ADHERINNE, R. (1986) HPLC method for determination of inositol Cereals and Legumes. CRC Press, Boca Raton.

SAS, 1990. Statistical Analysis Systems software package version 8.1. Statistical Analysis Systems Institute, Inc., Cary, NC, USA. 
1 SCHONER, F. J., HOPPE, P. P., SCHWARZ, G. \& WIESCHE, H. (1993) Comparison of 2 microbial phytase and inorganic-phosphate in male chickens - the influence on 3 performance and mineral retention at various calcium levels. Journal of Animal $4 \quad$ Physiology and Animal Nutrition, 69: 235-244.

5 SEBAStiAn, S., TOUCHBURN, S., CHAVEZ, E. R. \& LAGUE, P. C. (1996a) The effects 6 7 8

SEBASTIAN, S., TOUCHBURN, S., CHAVEZ, E. R. \& LAGUE, P. C. (1996b) Efficacy of supplemental microbial phytase at different dietary calcium levels on growth performance and mineral utilization of broiler chickens. Poultry Science, 75: 1516-1523.

SINGH, P. K., KHATTA, V. K., THAKUR, R. S., DEY, S. \& SANGWAN, M. L. (2003) Effect of phytase supplementation on the performance of broiler chickens fed maize and wheat based diets with different levels of non-phytate phosphorus. Asian-Australasian Journal of Animal Sciences, 16: 1642-1649.

SKIBA, F., CAllu, P., CASTAING, J., PABOEUF, F., CHAUVEL, J. \& JONDREVILlE, C. (2004) Variabilité intra-matière première de la digestibilité du phosphore des céréales et du pois chez le porc en croissance. Journées de la Recherche Porcine en France, 36: 910.

TRAN, G. \& SKIBA, F. (2005) Variabilité inter et intra matière première de la teneur en phosphore total et phytique de l'activité phytasique. INRA Productions Animales, 18: 159168. 
1 Viveros, A., CEnTENO, C., BREnes, A., CANAles, R. \& LOZANO, A. (2000)

2 Phytase and acid phosphatase activities in plant feedstuffs. Journal of Agricultural and $3 \quad$ Food Chemistry, 48: 4009-4013.

4 VIEIRA, S.L., PENZ, A.M., KESSLER, A.M. \& CATELLAN, E.V., Jr (1995) A nutritional 5 evaluation of triticale in broiler diets. Journal of Applied Poultry Research, 4: 352-355.

6 ZACARIAS, I., YANEZ, E., ESCOBAR, M., HEWSTONE, C. \& WULF, H. (1982) 7 Chemical and nutritional evaluation of triticale (Secale sp.) cultivated in Chili. Archivos $8 \quad$ Latinoamericanos de Nutrition, 32: 713-724.

9 ZHANG, Z. B., KORNEGAY, E. T., RADCLIFFE, J. S., DENBOW, D. M., VEIT, H. P. \& 10 LARSEN, C. T. (2000) Comparison of genetically engineered microbial and plant phytase 11 for young broilers. Poultry Science, 79: 709-717.

12 ZIMMERMANN, B., LANTZSCH, H. J., MOSENTHIN, R., BIESALSKI, H. K. \& 13 DROCHNER, W. (2002) Comparative evaluation of the efficacy of cereal and microbial 14 phytases in growing pigs fed diets with marginal phosphorus supply. Journal of the 15 Science of Food and Agriculture, 82: 1298-1304. 
Table 1. Physical and chemical characteristics ${ }^{1}$ of 30 batches of triticale

\begin{tabular}{|c|c|c|c|c|c|c|c|c|c|c|c|}
\hline Variety $^{2}$ & Origin & $\begin{array}{c}\mathrm{TGW} \\
\mathrm{g} \\
\end{array}$ & $\begin{array}{c}\mathrm{SW} \\
\mathrm{kg} / \mathrm{hl}\end{array}$ & $\begin{array}{c}\text { HFN } \\
\mathrm{s} \\
\end{array}$ & $\begin{array}{l}\mathrm{DM} \\
\mathrm{g} / \mathrm{kg}\end{array}$ & $\begin{array}{c}\mathrm{N} \\
\mathrm{g} / \mathrm{kg}\end{array}$ & $\begin{array}{c}\mathrm{P} \\
\mathrm{g} / \mathrm{kg}\end{array}$ & $\begin{array}{c}\text { Phytic P } \\
\text { g/kg }\end{array}$ & $\begin{array}{c}\mathrm{PA} \\
\mathrm{PU} / \mathrm{kg}\end{array}$ & $\begin{array}{l}\mathrm{PAV} \\
\mathrm{mL} / \mathrm{g} \\
\end{array}$ & $\begin{array}{l}\mathrm{RAV} \\
\mathrm{mL} / \mathrm{g}\end{array}$ \\
\hline Trimaran & France & 45.0 & 70.7 & 76 & 865 & 15,9 & 2.63 & 1.53 & 1023 & 2.35 & 1.79 \\
\hline A & France & 47.0 & 69.8 & 67 & 871 & 16,1 & 3.11 & & 987 & 2.89 & 1.84 \\
\hline Capitale & France & 46.5 & 74.8 & 62 & 869 & 15,7 & 2.83 & 2.12 & 1226 & 3.42 & 1.76 \\
\hline Vision & Germany & 57.5 & 75.5 & 109 & 874 & 16,1 & 3.13 & & 974 & 3.56 & 2.28 \\
\hline $\mathrm{B}$ & Germany & 48.5 & 72.3 & 84 & 856 & 16,1 & 2.75 & & 842 & 3.92 & 2.01 \\
\hline Galtjo & Netherlands & 55.0 & 75.2 & 260 & 857 & 17,1 & 3.22 & & 728 & 3.84 & 1.97 \\
\hline Ego & Netherlands & 53.5 & 73.9 & 158 & 857 & 15,0 & 3.11 & 2.32 & 1287 & 4.57 & 1.94 \\
\hline $\mathrm{C}$ & Sweden & 45.5 & 73.0 & 70 & 853 & 14,6 & 2.83 & & 881 & 3.50 & 1.83 \\
\hline $\mathrm{D}$ & Slovakia & 53.0 & 72.2 & 64 & 862 & 17,2 & 2.75 & & 1098 & 3.22 & 1.88 \\
\hline Colina & Romania & 58.5 & 71.0 & 62 & 858 & 16,1 & 2.83 & 2.62 & 1346 & 2.44 & 2.07 \\
\hline E & Romania & 54.5 & 74.5 & 75 & 859 & 17,8 & 3.57 & & 1067 & 4.65 & 2.86 \\
\hline $\mathrm{F}$ & Poland & 47.5 & 73.9 & 224 & 859 & 18,1 & 3.29 & 2.54 & 691 & 4.61 & 2.36 \\
\hline $\mathrm{G}$ & Poland & 56.0 & 73.2 & 68 & 853 & 16,6 & 2.91 & & 993 & 3.74 & 2.20 \\
\hline Binova & Germany & 41.5 & 70.8 & 146 & 850 & 14,9 & 2.98 & & 722 & 4.24 & 2.28 \\
\hline $\mathrm{H}$ & Germany & 54.0 & 72.5 & 92 & 858 & 14,9 & 3.21 & & 970 & 2.57 & 2.01 \\
\hline I & Poland & 48.0 & 71.4 & 65 & 858 & 16,6 & 2.36 & & 807 & 3.20 & 2.19 \\
\hline $\mathrm{J}$ & Poland & 54.0 & 73.4 & 68 & 867 & 16,9 & 3.13 & & 731 & 3.12 & 2.78 \\
\hline K & Poland & 46.0 & 73.6 & 97 & 869 & 17,8 & 2.96 & 2.58 & 447 & 3.29 & 2.07 \\
\hline $\mathrm{L}$ & Poland & 54.5 & 73.4 & 67 & 868 & 14,4 & 2.74 & & 848 & 4.43 & 2.40 \\
\hline M & Slovakia & 50.0 & 69.3 & 114 & 870 & 17,7 & 2.73 & & 880 & 3.20 & 2.35 \\
\hline Aubrac & France & 40.5 & 73.2 & 92 & 874 & 15,4 & 2.50 & 1.50 & 1103 & 3.86 & 2.32 \\
\hline Calao & France & 41.5 & 68.1 & 62 & 858 & 16,1 & 2.83 & 1.95 & 1700 & 3.97 & 2.70 \\
\hline DI34-2 & France & 54.0 & 71.5 & 103 & 861 & 16,5 & 2.93 & 2.21 & 768 & 2.95 & 2.45 \\
\hline $\mathrm{N}$ & France & 43.0 & 66.7 & 66 & 865 & 17,5 & 2.53 & 2.07 & 1843 & 3.52 & 2.06 \\
\hline $\mathrm{O}$ & France & 49.0 & 74.4 & 94 & 859 & 15,4 & 2.06 & & 1604 & 3.12 & 1.71 \\
\hline $\mathrm{P}$ & France & 55.5 & 73.0 & 64 & 855 & 16,4 & 2.89 & & 1064 & 2.87 & 2.01 \\
\hline Q & France & 49.5 & 74.6 & 119 & 871 & 14,6 & 2.54 & & 803 & 4.47 & 2.63 \\
\hline $\mathrm{R}$ & France & 52.0 & 75.3 & 130 & 873 & 16,2 & 2.65 & 2.54 & 638 & 2.72 & 2.01 \\
\hline $\mathrm{S}$ & France & 53.0 & 71.3 & 65 & 864 & 14,1 & 2.62 & & 1101 & 4.12 & 1.98 \\
\hline $\mathrm{T}$ & France & 52.0 & 71.3 & 68 & 873 & 16,4 & 3.21 & & 1360 & 3.51 & 1.90 \\
\hline Mean & & 50.2 & 72.4 & 96 & 863 & 16,1 & 2.86 & 2.18 & 1018 & 3.53 & 2.15 \\
\hline $\mathrm{SD}$ & & 5.0 & 2.1 & 48 & 7 & 1,09 & 0.31 & 0.40 & 319 & 0.66 & 0.31 \\
\hline Min & & 40.5 & 66.7 & 62 & 850 & 14,1 & 2.06 & 1.50 & 447 & 2.35 & 1.71 \\
\hline $\operatorname{Max}$ & & 58.5 & 75.5 & 260 & 874 & 18,1 & 3.57 & 2.62 & 1843 & 4.65 & 2.86 \\
\hline
\end{tabular}

3 TGW, thousand grain weight; SW, specific weight; HFN, Hagberg falling number; DM, dry matter; PA, phytase

4 activity; PAV, potential applied viscosity; RAV, real applied viscosity.

$58 \quad 5 \quad 2$ cultivars or selection lines. 
Table 2. Composition and analytical characteristics of the experimental diets

\begin{tabular}{|c|c|c|c|c|c|}
\hline Diet & 1 to 3 & 4 to $12^{1}$ & & 1 to 3 & 4 to $12^{1}$ \\
\hline Ingredients & \multicolumn{2}{|c|}{$(\mathrm{g} / \mathrm{kg}$ diet as fed $)$} & Analytical characteristics & (/ kg diet) & \\
\hline Maize & 450 & 0 & Metabolisable energy, $\mathrm{MJ}^{4}$ & 13.2 & 13.3 \\
\hline Soybean meal & 230 & 230 & Protein $(\mathrm{N} \times 6.25), \mathrm{g}^{4}$ & 216 & 216 to 219 \\
\hline Soy isolate & 70 & 60 & Crude fibre, $g^{4}$ & 42 to 40 & 36 \\
\hline Triticale & 0 & 450 & Lysine $^{4}$ & 12.0 & 12.0 \\
\hline Maize starch & 110 & 125 & Methionine + Cystine ${ }^{4}$ & 9.0 & 9.0 \\
\hline Wheat straw $^{2}$ & 59 to 54 & 39 & $\mathrm{Ca}, \mathrm{g}^{4}$ & 10.6 & 10.6 \\
\hline Vegetable oil & 45 & 60 & $P, g^{5}$ & 3.5 to 5.7 & 3.2 to 3.8 \\
\hline Calcium carbonate $^{2}$ & 25 to 21 & 25 & Phytic P, ${ }^{4}$ & 2.2 & 2.0 to 2.3 \\
\hline Monocalcium phosphate $^{2}$ & 0.0 to 8.8 & 0.0 & Phytase activity, $\mathrm{PU}^{5}$ & $<50$ & 135 to 1390 \\
\hline DL-methionine & 2.0 & 2.0 & $\mathrm{RAV}, \mathrm{mL} / \mathrm{g}^{5}$ & 0.63 to 0.80 & 0.96 to 1.40 \\
\hline Sodium chloride & 3.0 & 3.0 & & & \\
\hline Minerals and vitamins premix ${ }^{3}$ & 6.0 & 6.0 & & & \\
\hline
\end{tabular}
treated, variety DI34-2, Trimaran, Aubrac and Calao in diets 8, 9, 10 and 11, respectively; variety Calao, $200 \mathrm{~g} / \mathrm{kg}$ without heat treatment and $250 \mathrm{~g} / \mathrm{kg}$ heat-treated in diet 12 . Heat treatment, which aimed at reducing phytase activity, consisted in two successive heating in a microwave oven at $600 \mathrm{~W}$ for 2 minutes.

${ }^{2}$ Wheat straw: 59, 56 and 54; calcium carbonate, 25, 23 and 21; monocalcium phosphate, $0.0,4.4$ and $8.8 \mathrm{~g} / \mathrm{kg}$ in diets 1,2 and 3, respectively.

${ }^{3}$ Vitamin-trace mineral mix that provided the following per $\mathrm{kg}$ diet: vitamin A (retinyl acetate), $10000 \mathrm{IU}$; vitamin D3 (cholecalciferol), 4000 IU; vitamin E (DL-alpha-tocopherol), 80 mg; vitamin K3 (menadione), 4 mg; vitamin B1 (thiamin), $4 \mathrm{mg}$; vitamin B2 (riboflavin), $6.4 \mathrm{mg}$; vitamin B3 (PP, niacin), $80 \mathrm{mg}$; vitamin B5 (Ca pantothenate), 20 mg; vitamin B6 (pyridoxine), $5.6 \mathrm{mg}$; vitamin B8 (biotin, H), $0.2 \mathrm{mg}$; vitamin B9 (folic acid), $2.4 \mathrm{mg}$; vitamin B12 (cyanocobalamin), $0.016 \mathrm{mg}$; choline, $440 \mathrm{mg}, \mathrm{Fe}\left(\mathrm{FeSO}_{4}\right), 40 \mathrm{mg}$; $\mathrm{Cu}\left(\mathrm{CuSO}_{4}\right), 16 \mathrm{mg} ; \mathrm{Mn}(\mathrm{MnO}), 64 \mathrm{mg} ; \mathrm{Zn}$ $\left(\mathrm{ZnSO}_{4}\right), 72 \mathrm{mg} ; \mathrm{Co}\left(\mathrm{CoSO}_{4}\right), 0.5 \mathrm{mg}$; $\left(\mathrm{Ca}\left(\mathrm{IO}_{3}\right)_{2}\right), 1.6 \mathrm{mg} ; \mathrm{Se}\left(\mathrm{Na}_{2} \mathrm{SeO}_{3}\right), 0.16 \mathrm{mg}$.

${ }^{4}$ Estimated from INRA (1989) and the analysed N and phytic P concentrations in the four varieties of triticale.

${ }^{5}$ Analysed according to the methods described in the materials and methods section: P, 3.5, 4.5, 5.7, 3.8, 3.2, 3.6, 3.6, $3.7,3.3,3.3,3.7$ and $3.8 \mathrm{~g} / \mathrm{kg}$; phytase activity, $<50,<50,<50,620,875,920,1390,180,200,180,135$ and 645 PU/kg; RAV, Real Applied Viscosity, 0.76, 0.63, 0.80, 1.04, 0.96, 1.08, 1.03, 1.16, 1.13, 1.40, 1.22 and 1.02 ml/g in diets $1,2,3,4,5,6,7,8,9,10,11$ and 12 , respectively. 
Table 3. Correlation coefficient $(\mathrm{r})^{1}$ between physical and chemical characteristics ${ }^{2}$ of the 30 batches of 2

\section{triticale}

\begin{tabular}{llllllllll}
\hline & TGW & SW & HFN & DM & N & P & Phytic $\mathrm{P}^{3}$ & PA & PAV \\
\hline SW & $0.42(*)$ & & & & & & & & \\
HFN & 0.04 & $0.38\left(^{*}\right)$ & & & & & & & \\
DM & -0.05 & 0.09 & -0.14 & & & & & & \\
N & 0.05 & -0.11 & 0.19 & 0.05 & & & & & \\
P & 0.35 & 0.20 & 0.31 & -0.11 & 0.32 & & & & \\
Phytic $\mathrm{P}^{3}$ & $0.66(*)$ & 0.34 & 0.40 & -0.27 & 0.45 & $0.60\left(^{*}\right)$ & & & \\
PA & -0.15 & $-0.46(*)$ & $-0.38(*)$ & -0.05 & -0.10 & -0.27 & -0.36 & & \\
PAV & 0.06 & 0.00 & 0.03 & 0.05 & 0.21 & 0.29 & -0.03 & -0.18 & \\
RAV & -0.13 & 0.21 & 0.35 & -0.13 & -0.12 & 0.23 & 0.03 & -0.03 & $0.43(*)$ \\
\hline
\end{tabular}

$3 \stackrel{*}{*}, P<0.05$.

$4 \quad{ }^{2} \mathrm{TGW}$, thousand grain weight; SW, specific weight; HFN, Hagberg falling number; DM, dry matter; PA, phytase 5 activity; PAV, potential applied viscosity; RAV, real applied viscosity.

$6 \quad{ }^{3} n=11$. 
1

3

4

5

6

7

8

9

10

11

12

13

14

15

16

17

182

19

20

21

Table 4. Phytase activity in 5 varieties of triticale

\begin{tabular}{lcc}
\hline Variety & $\mathrm{n}$ & Phytase activity, PU/kg ${ }^{1}$ \\
\hline DI34-2 & 4 & $1012 \pm 102 \mathrm{a}$ \\
Aubrac & 6 & $1320 \pm 87 \mathrm{~b}$ \\
Trimaran & 6 & $1424 \pm 125 \mathrm{~b}$ \\
Capitale & 4 & $1815 \pm 126 \mathrm{c}$ \\
Calao & 6 & $2146 \pm 145 \mathrm{~d}$ \\
& & \\
$P$ & & $<0.001$ \\
RSD $^{2}$ & &
\end{tabular}

${ }^{1}$ values are means \pm standard deviation.

${ }^{2} \mathrm{RSD}$, residual standard deviation.

a-d; Means within a column not followed by the same letter differ at $P<0.05$. 
Table 5. Growth performance and bone ${ }^{I}$ characteristics in chickens given the maize-based diets supplemented with graded levels of $P$ as monocalcium phosphate or the triticale-based diets containing graded levels of phytase ${ }^{2}$

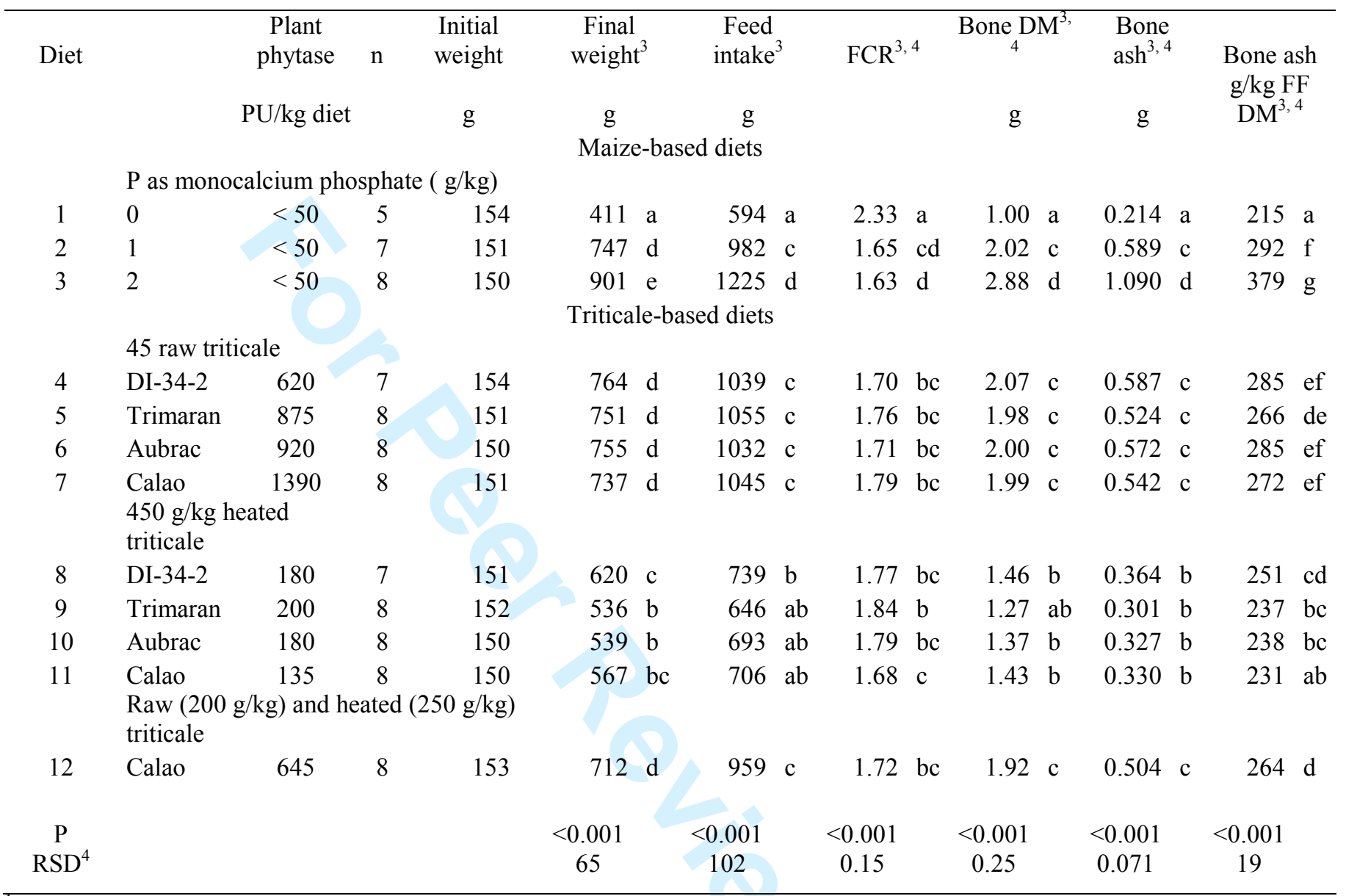

${ }^{\mathrm{T}}$ Right tibiotarsus.

${ }^{2}$ Values are given on the basis of one cage of two birds.

${ }^{3}$ Linear $(\mathrm{L})$ and quadratic $(\mathrm{Q})$ effects of $\mathrm{P}$ added as monocalcium phosphate $(\mathrm{g} / \mathrm{kg}$ diet) and of phytase activity in the $\operatorname{diet}(\mathrm{PU} / \mathrm{kg}$ diet):

48 Final weight: $\mathrm{P}$ added, L $(P<0.001), \mathrm{Q}(P<0.01)$; phytase activity, $\mathrm{L}(P<0.001), \mathrm{Q}(P<0.001), \mathrm{RSD}=69, \mathrm{R}^{2}=0.77$.

Feed intake: P added, L $(P<0.001), \mathrm{Q}(P<0.05)$; phytase activity, $\mathrm{L}(P<0.001), \mathrm{Q}(P<0.001), \mathrm{RSD}=104, \mathrm{R}^{2}=0.78$.

FCR: P added, L $(P<0.01), \mathrm{Q}(P<0.05)$; phytase activity, $\mathrm{L}(P<0.001), \mathrm{Q}(P<0.01), \mathrm{RSD}=0.19, \mathrm{R}^{2}=0.23$.

Bone DM: P added, L $(P<0.001)$; phytase activity, L $(P<0.001), \mathrm{Q}(P<0.001), \mathrm{RSD}=0.25, \mathrm{R}^{2}=0.78$.

Bone ash (g): P added, L ( $P<0.001)$; phytase activity, L $(P<0.001), \mathrm{Q}(P<0.001), \mathrm{RSD}=0.075, \mathrm{R}^{2}=0.90$.

Bone ash (g/kg FF DM): P added, L $(P<0.001)$; phytase activity, L $(P<0.001)$, Q $(P<0.001), \mathrm{RSD}=20, \mathrm{R}^{2}=0.81$.

$5514 \quad{ }^{4} \mathrm{DM}$, dry matter; FF DM, fat-free dry matter; FCR, feed conversion ratio; RSD, residual standard deviation. 
Table 6. Adjustment of final weight, feed intake, bone $e^{l}$ ry matter and bone ash to P as monocalcium 3 phosphate (MCP, g/kg diet) and phytase activity (PU/kg diet) and equivalency values of $P$ as $M C P(g)$ for plant phytase (PU)

\begin{tabular}{|c|c|c|c|c|c|}
\hline & $\begin{array}{c}\text { Final weight }^{3} \\
\mathrm{~g}\end{array}$ & $\begin{array}{c}\text { Feed intake }^{3} \\
\mathrm{~g}\end{array}$ & $\begin{array}{c}\text { Bone FF DM } \\
\mathrm{g} \\
\end{array}$ & $\begin{array}{c}{\text { Bone } \text { ash }^{4}}_{\mathrm{g}} \\
\end{array}$ & $\begin{array}{c}{\text { Bone } \text { ash }^{4}} \text { g/kg FF DM }\end{array}$ \\
\hline \multicolumn{6}{|c|}{ Non-linear adjustment ${ }^{2}$} \\
\hline \multicolumn{6}{|c|}{ Coefficients $^{2}$} \\
\hline $\mathrm{a}$ & 409 & 553 & 0.996 & 0.180 & 211 \\
\hline $\mathrm{b}$ & 621 & 990 & 0.958 & 0.446 & 83.3 \\
\hline $\mathrm{c}$ & 353 & 571 & 1.09 & 0.393 & 67.1 \\
\hline 1 & 0.786 & 0.568 & & & \\
\hline $\mathrm{k}$ & 0.00352 & 0.00200 & 0.00281 & 0.00303 & 0.00338 \\
\hline $\mathrm{R}^{2}$ & 0.77 & 0.77 & 0.77 & 0.89 & 0.81 \\
\hline RSD & 67 & 105 & 0.25 & 0.075 & 20 \\
\hline \multicolumn{6}{|l|}{ Equivalency values ${ }^{5}$} \\
\hline Plant phytase (PU) & & $\mathrm{Pa}$ & monocalcium phos & hate $(\mathrm{g})$ & \\
\hline 150 & 0.34 & 0.29 & 0.42 & 0.32 & 0.32 \\
\hline 250 & 0.52 & 0.45 & 0.60 & 0.47 & 0.46 \\
\hline 500 & 0.81 & 0.80 & 0.89 & 0.69 & 0.66 \\
\hline 750 & 0.96 & 1.05 & 1.02 & 0.79 & 0.74 \\
\hline 1000 & 1.02 & 1.22 & 1.08 & 0.84 & 0.78 \\
\hline 1250 & 1.05 & 1.33 & 1.11 & 0.86 & 0.79 \\
\hline
\end{tabular}

$5 \quad{ }^{\mathrm{T}}$ Right tibiotarsus.

$6{ }^{2}$ Models were generated using treatment means, $R^{2}$ (coefficient of determination) and RSD (residual standard 7 deviation) are calculated relative to individual observations.

$8{ }^{3}$ The model was $\mathrm{Y}=\mathrm{a}+\mathrm{b}\left(1-\mathrm{e}^{-1 \mathrm{MinP}}\right)+\mathrm{c}\left(1-\mathrm{e}^{-\mathrm{kPhyt}}\right)$, with $\mathrm{Y}=$ response measurement, MinP $=\mathrm{P}$ added as MCP (g/kg diet), Phyt = phytase activity (PU/kg diet).

${ }^{4}$ The model was $\mathrm{Y}=\mathrm{a}+\mathrm{b} \operatorname{MinP}+\mathrm{c}\left(1-\mathrm{e}^{-\mathrm{k} \text { Phyt }}\right)$, with $\mathrm{Y}=$ response measurement, MinP $=\mathrm{P}$ added as MCP $(\mathrm{g} / \mathrm{kg}$ diet $)$, Phyt $=$ phytase activity (PU/kg diet).

${ }^{5}$ Final weight, feed intake, calculated as $\mathrm{MinP}=-1 / 1 \ln \left[1-\mathrm{A}\left(1-\mathrm{e}^{-\mathrm{k} \text { Phyt }}\right)\right]$; Bone dry matter and bone ash, calculated as MinP $=\mathrm{A}\left(1-\mathrm{e}^{-\mathrm{kPhy}}\right)$, with $\mathrm{A}=\mathrm{c} / \mathrm{b}, \operatorname{MinP}=\mathrm{P}$ as MCP $(\mathrm{g})$, Phyt $=$ phytase activity (PU)

\footnotetext{
${ }^{6}$ FF DM, fat-free dry matter.
} 
Figure heading

1

2 Figure. Response of final weight and bone ${ }^{l}$ ash to $P$ as monocalcium phosphate in maize based diets and 3 to plant phytase in triticale based diets.

Figure footnotes

8

19

20 


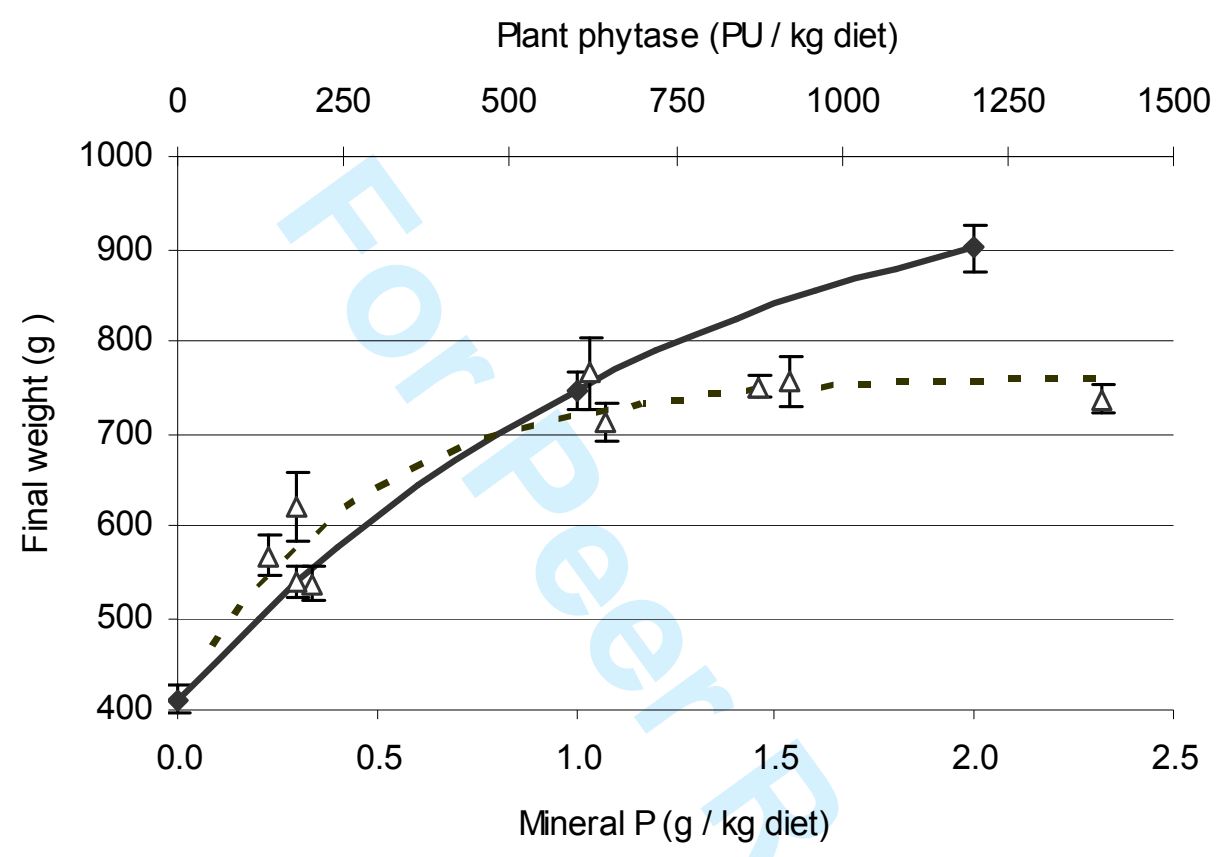

- Maize diets $\Delta$ Triticale diets

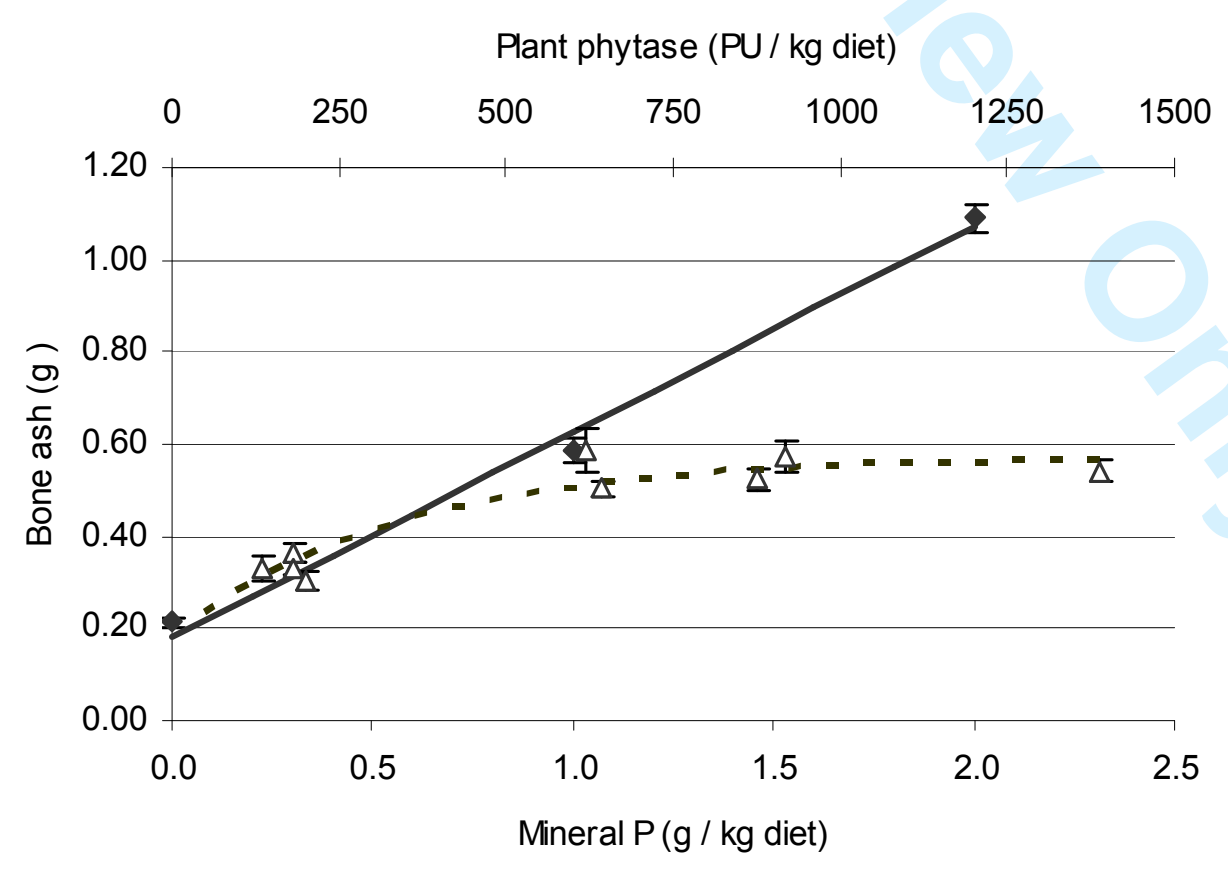

- Maize diets $\Delta$ Triticale diets 